\title{
Phytochemical Contents and Antioxidant Activity of Medicinal Plants from the Rubiaceae Family in Thailand
}

\author{
Rungcharn Suksungworn \& Sutsawat Duangsrisai* \\ Phyto-Chemodiversity and Ecology Research Unit, Department of Botany, Faculty of Science, Kasetsart University, Bangkean, Bangkok 109 00, \\ Thailand \\ *Email: fscissw@ku.ac.th
}

\section{ARTICLE HISTORY}

Received: 02 August 2020

Accepted: 19 October 2020

Published: 01 January 2021

KEYWORDS

Anti-radical

Traditional medicine

Herbal medicine

Nature products

\section{ABSTRACT}

Several plants of the Rubiaceae family possess potential pharmacological properties, such as antioxidant activity, for subsequent drug development. We investigated the methanolic extracts from the bark and wood of five Rubiaceae species for phenolic and flavonoid contents and antioxidant activity. Regarding the phytochemical contents and antioxidant activity, Mitragyna diversifolia wood (437.57 $\left.\pm 9.90 \mathrm{mg} \mathrm{GAE} \mathrm{g}^{-1}\right)$ and Haldina cordifolia wood $\left(30.11 \pm 0.20 \mathrm{mg} \mathrm{QE} \mathrm{g}^{-1}\right)$ displayed the highest total phenolic content (TPC) and total flavonoid content (TFC) respectively. Morinda coreia bark followed the highest antioxidant activities $\left(\mathrm{IC}_{50}=360.58 \pm 19.28 \mu \mathrm{g} \mathrm{ml}^{-1}\right)$ in the 2,2-diphenyl-1picrylhydrazyl radical scavenging activity (DPPH), Catunaregam tomentosa bark $\left(\mathrm{IC}_{50}=13.96 \pm 5.32 \mu \mathrm{g}\right.$ $\left.\mathrm{ml}^{-1}\right)$ in the nitric oxide radical scavenging activity (NO), M. coreia wood $\left(\mathrm{IC}_{50}=918.27 \pm 0.16 \mu \mathrm{g} \mathrm{ml}^{-1}\right)$ in the superoxide radical scavenging activity $(\mathrm{SO})$ and $\mathrm{M}$. coreia wood $\left(\mathrm{IC}_{50}=236.65 \pm 1.66 \mathrm{\mu g} \mathrm{m}^{-1}\right)$ in ferric reducing antioxidant power activity (FRAP). The TPC and TFC displayed strong correlations with DPPH in M. diversifolia wood and with FRAP in M. diversifolia bark and wood. We found high correlation between TFC and FRAP in all plant extracts except $C$. tomentosa wood, while no relation was detected between TFC and NO in all plant extracts. Comparing Rubiaceae species, the highest antioxidant potential were showed in C. tomentosa bark. Overall, it is worth mentioning that the Rubiaceae species exhibit potential as a promising source of natural antioxidants.

\section{Introduction}

Reactive oxygen species (ROS) are a class of chemical products that are formed from oxygen metabolism and largely contribute to oxidative stress, which damages lipids, proteins and DNA (1,2). Common ROS include the hydroxyl radical, hydrogen peroxide, superoxide radicals, hydroxyl ion and nitric oxide. Various environmental stresses lead to excessive ROS production, causing progressive oxidative damage, such as high irradiance, pollution, metal toxicity, UV radiation and pathogenic infection $(2,3)$. Since oxidation and oxidative damage to cellular components and biomolecules have been related to several diseases, many studies have investigated the relationship between oxidative damage and cancer (4), liver disease (5), Alzheimer's disease (6), aging (7), arthritis (8), inflammation (9), diabetes (10), Parkinson's disease (11), atherosclerosis (12) and
AIDS (13). Based on such literature, medicinal plants are commonly used to treat diseases due to their therapeutic properties and powerful antioxidant activity.

Rubiaceae is a one of the largest families of angiosperms, well known for its high diversity of secondary metabolites. Various species from the Rubiaceae family have proven to be a promising source for the development of new potential metabolites and drug prototypes because of their diversity and pharmacology properties (14). Their wide range of secondary metabolites include anthraquinones, alkaloids, coumarins, flavonoids and terpenes, which display pharmacological properties (15). Based on literature, medicinal plants from the Rubiaceae family have been reported to possess rich antioxidant activity (16-20), supporting their use in therapeutics.

(C) Suksungworn \& Duangsrisai (2021). This is an open-access article distributed under the terms of the Creative Commons Attribution License, which permits unrestricted use, distribution and reproduction in any medium, provided the original author and source are credited (https://creativecommons.org/licenses/by/4.0/).

To cite this article: Suksungworn R, Duangsrisai S. Phytochemical Contents and Antioxidant Activity of Medicinal Plants from the Rubiaceae Family in Thailand Plant Science Today. 2021;8(1):24-31. https://doi.org/10.14719/pst.2021.8.1.882 
For this study, the plant samples were obtained from a woody plant to evaluate the phenolic compounds and potential biological properties, especially in the bark (21). Moreover, the woody part contains various secondary metabolites with potential biological activities (22). Hence, this study investigated the antioxidant activity and quantified phenolic and flavonoid content of selected woody medicinal plants from the Rubiaceae family in Thailand.

\section{Materials and Methods}

\section{Collection of plant material}

Five species of the Rubiaceae family, including Catunaregam tomentosa (Blume ex DC.) Tirveng., Haldina cordifolia (Roxburgh) Ridsdale., Mitragyna diversifolia (Wallich ex G. Don) Haviland., Mitragyna rotundifolia (Roxburgh) Kuntze. and Morinda coreia Buch.-Ham. were collected same location at Chainat province, Thailand in March 2015. We identified the plants at Bangkok Forestry Herbarium (BKF in Bangkok, Thailand). The voucher specimens of the plants (PCERU_CT1, PCERU_HC1, PCERU_MD1, PCERU_MR1 and PCERU_MC1) were deposited in the Department of Botany, Kasetsart University, Bangkok, Thailand.

Methanol (analytical grade) was obtained from Merck (Darmstadt, Germany). Other reagents and chemicals included 2,2-diphenyl-1-picrylhydrazyl (DPPH; Merck, USA), tris-HCl buffer (Tris; Amresco, USA), nitroblue tetrazolium (NBT; Sigma-Aldrich, China), $b$-nicotinamide adenine dinucleotide (NADH; Sigma, Germany), phenazine methosulfate (PMS; Sigma, Ukranine), sodium nitroprusside (SNP; Himedia, India), sulfanilamide (Carlo Erba, France), phosphoric acid (Macron Fine Chemicals, China), naphthaylethylenediamine hydrochloride (AppliChem Panreac, Germany), 2,4,6-tri(2-pyridyl)1,3,5-triazine (TPTZ; Fluka, Switzerland), ferric chloride (Chem-supply, Australia), Folin-Ciocalteu (Merck, USA), sodium carbonate (Merck, Germany), gallic acid (Merck, USA), aluminum trichloride (Univar, New Zealand), quercetin acid (SigmaAldrich, Germany), Whatman ${ }^{\circledR}$ grade 1 filtration paper (Sigma Aldrich, USA), Büchi Rotavapor ${ }^{\circledR}$ R-210 (Mumbai, India) and T60-Visible spectrophotometer (PG Instruments, United Kingdom).

\section{Preparation of crude extract}

The bark and wood samples were powdered coarsely using a mechanical grinder and macerated in absolute methanol for 7 days in the dark at room temperature (23). The extracts were filtered through filtration paper, evaporated to dryness in vacuum at $40{ }^{\circ} \mathrm{C}$ using a rotary evaporator, then stored at $-20{ }^{\circ} \mathrm{C}$ in the dark.

\section{Quantitative analysis of phenolic and flavonoid compounds}

\section{Total phenolic content}

The phenolic content of plant extracts was determined according to a previously described procedure (24). The sample $(0.5 \mathrm{ml})$ was mixed with
$0.2 \mathrm{~N}$ Folin-Ciocalteu reagent $(2.5 \mathrm{ml})$, left for $5 \mathrm{~min}$ at room temperature, added solution of $\mathrm{Na}_{2} \mathrm{CO}_{3}\left(75 \mathrm{~g} \mathrm{l}^{-1}\right.$ in water, $2 \mathrm{ml}$ ). After incubation for $1 \mathrm{hr}$, the absorbance was measured at $765 \mathrm{~nm}$. A calibration of standard curve was produced using gallic acid (0-300 $\mathrm{mg} \mathrm{l}^{-1}$ ). The results are expressed as $\mathrm{mg}$ of gallic acid equivalents (mg GAE g ${ }^{-1}$ ).

\section{Total flavonoid content}

The total flavonoid was measured based on the method described in a previous work (25). The sample $(1.5 \mathrm{ml})$ was mixed with $2 \% \mathrm{AlCl}_{3}$ in methanol (1.5 ml). The absorbance was read at $415 \mathrm{~nm}$ after 15 min against a blank sample. Quercetin (0-50 $\left.\mathrm{mg} \mathrm{l}^{-1}\right)$ was used as a standard compound to plot the curve. The results are expressed as gm of quercetin equivalents (mg QE g ${ }^{-1}$ ).

\section{DPPH radical scavenging activity}

DPPH scavenging activity was demonstrated using 2,2-diphenyl-1-picrylhydrazyl (DPPH) free radical (26). The sample $(1.5 \mathrm{ml})$ was mixed with $0.2 \mathrm{mM}$ DPPH solution in methanol (1.5 ml). After incubation for $30 \mathrm{~min}$, the absorbance was read at $520 \mathrm{~nm}$.

\section{Nitric oxide radical scavenging activity}

Nitric oxide, generated from SNP in solution at physiological $\mathrm{pH}$, interacts with oxygen to produce nitrite ions, which can be measured by the Griess reaction (27). The reaction mixture $(3 \mathrm{ml})$, containing sodium nitroprusside in phosphate PBS buffer and the extracts were incubated. After incubation for 150 minutes, the reaction mixture $(0.5 \mathrm{ml})$ was removed, then Griess reagent (1\% sulfanilamide, $2 \% \mathrm{H}_{3} \mathrm{PO}_{4}$ and $0.1 \%$ naphthaylethylene diamine hydrochloride, $0.5 \mathrm{ml}$ ) was added. The absorbance was measured at $546 \mathrm{~nm}$.

\section{Superoxide radical scavenging activity}

The NADH-PMS condition produced superoxide radicals according to a previously described procedure (28). The mixture contained samples $(1 \mathrm{ml}), 936 \mu \mathrm{M}$ NADH $(1 \mathrm{ml})$ and $300 \mu \mathrm{M}$ NBT $(1 \mathrm{ml})$. After 10 minutes, the reaction was initiated by adding $120 \mu \mathrm{M}$ PMS (1 ml). After incubation for $5 \mathrm{~min}$, the absorbance at $560 \mathrm{~nm}$ was compared against blank samples.

\section{Ferric reducing antioxidant power (FRAP) activity}

The ferric reducing antioxidant power (FRAP) activity was evaluated using the followed method from previous report (29). Fresh FRAP solution, containing $300 \mathrm{mM}$ acetate buffer $(100 \mathrm{ml}), 10 \mathrm{mM}$ TPTZ solution $(10 \mathrm{ml})$ and $20 \mathrm{mM} \mathrm{FeCl} \cdot 6 \mathrm{H}_{2} \mathrm{O}(10 \mathrm{ml})$, was kept warmed at $37^{\circ} \mathrm{C}$ until subsequently used. The sample $(0.15 \mathrm{ml})$ was mixed with FRAP solution $(2.85 \mathrm{ml})$ in the dark. After $30 \mathrm{~min}$, the absorbance was read at $593 \mathrm{~nm}$. The FRAP content in the sample was reported as mg trolox equivalent (TE) g extract ${ }^{-1}$.

\section{Data analysis}

The experimental treatments were performed in three independent replicates. Values are displayed as mean with standard deviation. The results of ANOVA analysis and Dunnett's multiple comparisons tests 

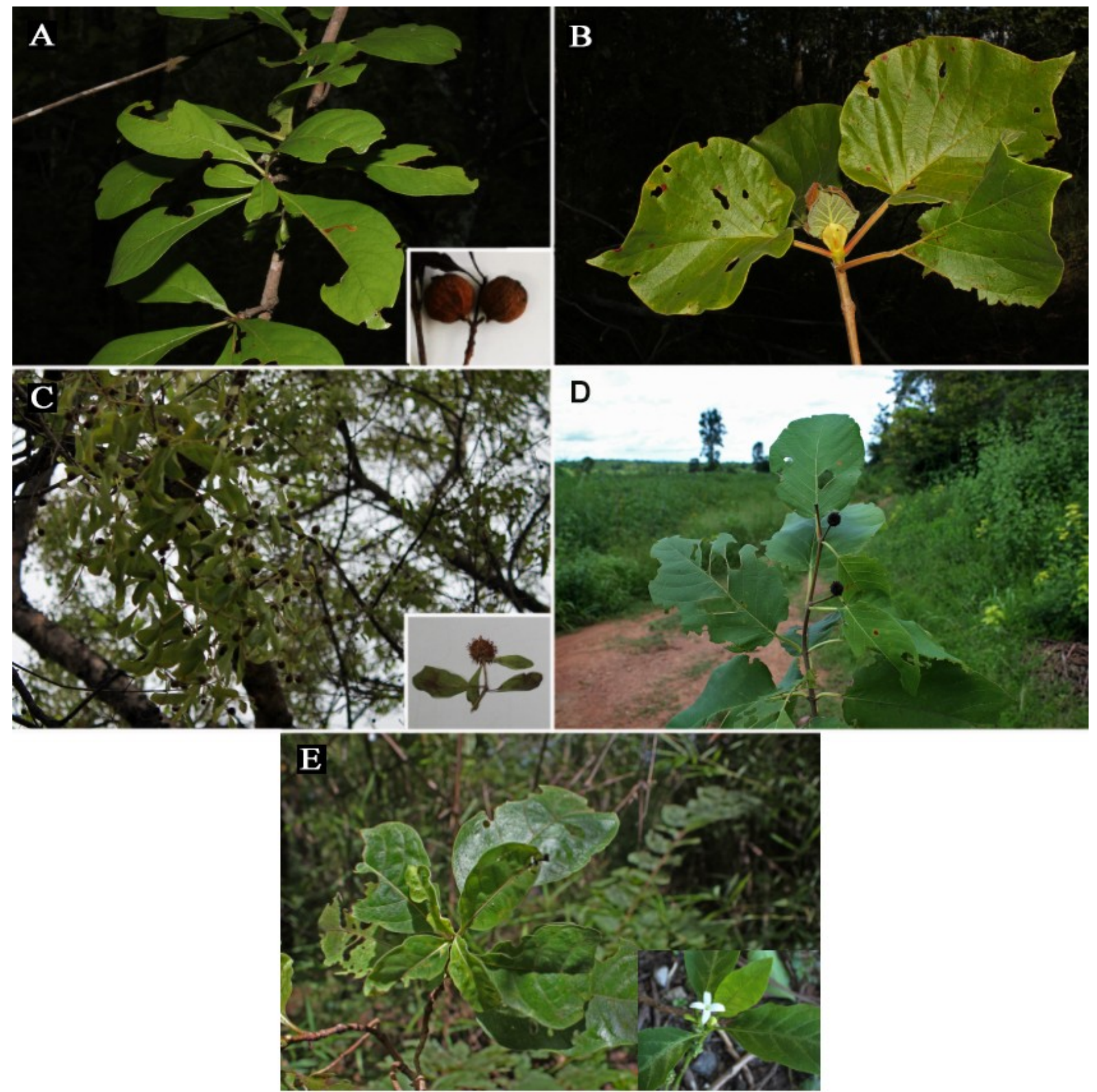

Fig. 1. Description of five Rubiaceae species; (A) Catunaregam tomentosa, (B) Haldina cordifolia, (C) Mitragyna diversifolia, (D) Mitragyna rotundifolia and (E) Morinda coreia.

were analyzed using GraphPad Prism 6 Software (San Diego, CA, USA) for statistical comparison. The $p$-value less than 0.05 were considered statistically significant.

\section{Results and Discussion}

In order to fully reflect the antioxidant activity of the five Rubiaceae species (Fig. 1), four well-known antioxidant methods, including 2,2-diphenyl-1picrylhydrazyl (DPPH), nitric oxide (NO), superoxide (SO) radical scavenging activity, and ferric reducing antioxidant power activity (FRAP), were employed. It is pertinent to measure various types of antioxidant activity because most antioxidants have several functions (30). Despite numerous studies on $C$. tomentosa fruit (31), H. cordifolia bark, leaves, stem and root (32-36) and M. rotundifolia bark and leaves (37), no existing work considers the chemical composition and antioxidant activity of $M$. diversifolia and $M$. coreia bark and wood.

\section{Determination of total phenolic and flavonoid content}

Quantification of total phenolic content (TPC) is usually carried out by the Folin-Ciocalteu method, while the $\mathrm{AlCl}_{3}$ method is used for determination of the total flavonoid content (TFC). The amount of TPC and TFC in the plant extracts are presented in Table 1. The TPC of plant extracts is presented the highest in $M$. diversifolia wood (437.57 $\left.\pm 9.90 \mathrm{mg} \mathrm{GAE} \mathrm{g}^{-1}\right)$ and the lowest in $M$. coreia bark (119.48 $\left.\pm 0.41 \mathrm{mg} \mathrm{GAE} \mathrm{g}^{-1}\right)$. On the other hand, the flavonoid content of plant extracts shown the highest in $H$. cordifolia wood (30.11 $\pm 0.20 \mathrm{mg} \mathrm{QE} \mathrm{g}^{-1}$ ) and the lowest in $M$. coreia bark $\left(0.74 \pm 0.01 \mathrm{mg} \mathrm{QE} \mathrm{g}^{-1}\right)$. In particular, phenols are one of the most effective antioxidants $(38,39)$, which possess strong redox properties that play a role in neutralizing and absorbing free radicals, quenching 
Table 1. Total phenolic content (TPC) and total flavonoid content (TFC); the results are presented as mean \pm standard in triplicate $(n=3)$.

\begin{tabular}{|c|c|c|c|c|c|}
\hline Plant extracts & Part & $\begin{array}{c}\text { TPC } \\
\left(m g \text { GAE g }{ }^{-1}\right)\end{array}$ & $\begin{array}{c}\text { TPC } \\
\text { ranking }\end{array}$ & 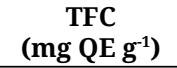 & $\begin{array}{c}\text { TFC } \\
\text { ranking }\end{array}$ \\
\hline Catunaregam tomentosa & bark & $396.38 \pm 0.41^{* * * *}$ & 4 & $4.32 \pm 0.02^{* * * *}$ & 5 \\
\hline Catunaregam tomentosa & wood & $285.67 \pm 7.01^{* * * *}$ & 7 & $1.49 \pm 0.01^{* * * *}$ & 8 \\
\hline Haldina cordifolia & bark & $359.24 \pm 3.67^{* * * *}$ & 6 & $5.05 \pm 0.13^{* * * *}$ & 4 \\
\hline Haldina cordifolia & wood & $258.29 \pm 3.27^{* * * *}$ & 9 & $30.11 \pm 0.20$ & 1 \\
\hline Mitragyna diversifolia & bark & $382.33 \pm 3.30^{* * * *}$ & 5 & $3.15 \pm 0.10^{* * * *}$ & 7 \\
\hline Mitragyna diversifolia & wood & $437.57 \pm 9.90$ & 1 & $1.48 \pm 0.01^{* * * *}$ & 9 \\
\hline Mitragyna rotundifolia & bark & $411.62 \pm 10.72^{* * * *}$ & 3 & $3.68 \pm 0.01^{* * * *}$ & 6 \\
\hline Mitragyna rotundifolia & wood & $412.81 \pm 0.41^{* * *}$ & 2 & $5.65 \pm 0.02^{* * * *}$ & 3 \\
\hline Morinda coreia & bark & $119.48 \pm 0.41^{* * * *}$ & 10 & $0.74 \pm 0.01^{* * * *}$ & 10 \\
\hline Morinda coreia & wood & $261.14 \pm 0.71^{* * * *}$ & 8 & $7.40 \pm 0.01^{* * * *}$ & 2 \\
\hline
\end{tabular}

Values followed by the asterisk symbol $(*)$ are statistically significant $(p<0.05)$ compared to the highest value of each activity based on Dunnett's multiple comparisons test.

of singlet and triplet oxygen, and the ability to chelate metals $(40,41)$. In additional, flavonoids are a group of naturally occurring polyphenolic compounds that serve as excellent hydrogen-/electron-donors. The resulting flavonoids radical is relatively stable due to electron delocalization and intramolecular hydrogen bonding (42). Compared to bark, some reports suggest that wood contains higher phenolic levels (43, 44) and is richer in polyphenols and resin acids (diterpenes). In the heartwood part, most soluble sugars such as xylose, mannose and arabinose can be derived from hydrolyses (45). Previous reports have demonstrated that the wood part of plants have various secondary metabolites with potential biological activities $(43,46,47)$. In this study, the highest TPC and TFC were found in $M$. diversifolia wood and $H$. cordifolia wood.

\section{DPPH radical scavenging activity}

DPPH radical scavenging activity has been widely used to evaluate the free radical scavenging activity of antioxidants or hydrogen donors. As shown in Table 2, the scavenging effects of plant extracts on DPPH radical were found the higest in $M$. coreia bark $\left(\mathrm{IC}_{50}=360.58 \pm\right.$ $19.28 \mu \mathrm{g} \mathrm{ml}^{-1}$ ) and the lowest in $\quad M$. coreia wood $\left(\mathrm{IC}_{50}=2408.18 \pm 73.82 \mu \mathrm{g} \mathrm{ml}^{-1}\right)$. The DPPH method is based on scavenging through the addition of a radical species or antioxidant with visually noticeable discoloration. The DPPH method is based on scavenging through the addition of a radical species or antioxidant with visually noticeable discoloration. The level of color change is proportional to the concentration and potency of the antioxidants (48). Concerning the $\mathrm{IC}_{50}$ value of $H$. cordifolia, the bark methanol extract from a previous study $\left(56.1 \mu \mathrm{g} \mathrm{ml}^{-1}\right.$ ) was found to be 7.3-fold higher than our DPPH test (411.80 $\left.\mu \mathrm{g} \mathrm{ml}^{-1}\right)$ (35). This result suggests that Rubiaceae plants are capable of donating hydrogen to a free radical to scavenge potential damage.

\section{Nitric oxide radical scavenging activity}

Nitrite $\left(\mathrm{NO}^{2-}\right)$ can be metabolized into nitric oxide (NO), which is an essential bio-regulatory molecule with physiological processes and functions. However, excessive NO can interact with the superoxide anion to form peroxynitrite ion $\left(\mathrm{ONOO}^{-}\right)$. Nitrite is detected and analysed by the formation of $\mathrm{NO}^{2-}$ containing the Griess reagent, while nitric oxide scavengers compete with oxygen, leading to reduced production of nitrite ions. According to the $\mathrm{IC}_{50}$ values in Table 2 , the inhibition of nitric oxide radical scavenging ability were presented the highest IC $_{50}$ value $(13.96 \pm 5.32 \mu \mathrm{g}$ $\mathrm{ml}^{-1}$ ) in $C$. tomentosa bark and the lowest $\mathrm{IC}_{50}$ value $\left(651.74 \pm 7.68 \mu \mathrm{g} \mathrm{ml}^{-1}\right)$ in $M$. coreia bark. Nitric oxide plays an important role in various inflammatory processes (27). The nitric oxide radical generated from sodium nitroprusside interacted with oxygen to form nitrite (49). Comparing $\mathrm{IC}_{50}$ values of $H$. cordifolia, the bark methanol extract from a previous study $\left(125.7 \mu \mathrm{g} \mathrm{ml}^{-1}\right)$ was found to be 2.7-higher than our result (342.57 $\mu \mathrm{g} \mathrm{m} \mathrm{m}^{-1}$ ) (35). The Rubiaceae extracts from our study inhibit nitrite formation by competing with oxygen to react with nitric oxide.

\section{Superoxide radical scavenging activity}

Superoxide radical scavenging activity (SO) is an antioxidant enzyme related to ROS scavengers and mediators in oxidative chain reactions. To evaluate the $\mathrm{O}^{2-}$ scavenging activity of antioxidants, the PMS$\mathrm{NADH}-\mathrm{NBT}$ system was employed. As shown in Table 2 , the scavenging activity of superoxide in plant

Table 2. Anti-oxidant activity of plant extracts; the results are presented in mean \pm standard in triplicate $(n=3)$.

\begin{tabular}{|c|c|c|c|c|c|}
\hline Plant extracts & Part & $\begin{array}{c}\mathrm{IC}_{50} \text { of DPPH } \\
\left(\mu \mathrm{g} \mathrm{ml}^{-1}\right)\end{array}$ & $\begin{array}{c}\mathrm{IC}_{50} \text { of NO } \\
\left(\mu \mathrm{ml}^{-1}\right)\end{array}$ & 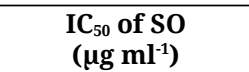 & $\begin{array}{c}\text { FRAP } \\
\left(\mathrm{mg} \mathrm{TE} \mathrm{g}^{-1}\right)\end{array}$ \\
\hline Catunaregam tomentosa & bark & $540.32 \pm 27.37^{\mathrm{ns}}$ & $13.96 \pm 5.32$ & $4150.13 \pm 45.35^{* * * *}$ & $206.86 \pm 1.33^{* * * *}$ \\
\hline Catunaregam tomentosa & wood & $380.60 \pm 99.65^{\mathrm{ns}}$ & $81.33 \pm 9.83^{* *}$ & $8295.09 \pm 641.25^{* * * *}$ & $96.10 \pm 6.29^{* * * *}$ \\
\hline Haldina cordifolia & bark & $411.80 \pm 10.69^{\mathrm{ns}}$ & $342.57 \pm 8.56^{* * * *}$ & $5236.43 \pm 41.50^{* * * *}$ & $199.98 \pm 0.44^{* * * * *}$ \\
\hline Haldina cordifolia & wood & $532.73 \pm 29.23^{\text {ns }}$ & $434.56 \pm 14.37^{* * * *}$ & $1204.94 \pm 19.25^{\text {ns }}$ & $61.54 \pm 0.07^{* * * *}$ \\
\hline Mitragyna diversifolia & bark & $1769.41 \pm 382.95^{* * * *}$ & $73.31 \pm 9.27^{* * * *}$ & $3615.47 \pm 7.69^{* * * * *}$ & $153.31 \pm 0.39^{* * * * *}$ \\
\hline Mitragyna diversifolia & wood & $795.34 \pm 8.95^{* *}$ & $259.69 \pm 14.98^{* * * * *}$ & $4516.30 \pm 16.07^{* * * *}$ & $62.30 \pm 0.32^{* * * *}$ \\
\hline Mitragyna rotundifolia & bark & $2225.30 \pm 64.51^{* * * *}$ & $52.65 \pm 6.66^{*}$ & $3179.04 \pm 22.44^{* * * *}$ & $95.97 \pm 0.39^{* * * *}$ \\
\hline Mitragyna rotundifolia & wood & $716.53 \pm 60.43^{*}$ & $183.94 \pm 15.14^{* * * * *}$ & $7036.50 \pm 92.69^{* * * *}$ & $222.76 \pm 0.26^{* * * * *}$ \\
\hline Morinda coreia & bark & $360.58 \pm 19.28$ & $651.74 \pm 7.68^{* * * *}$ & $6622.71 \pm 25.92^{* * * *}$ & $18.75 \pm 0.52^{* * * *}$ \\
\hline Morinda coreia & wood & $2408.18 \pm 73.82^{* * * *}$ & $183.52 \pm 31.27^{* * * *}$ & $918.27 \pm 0.16$ & $236.65 \pm 1.66$ \\
\hline
\end{tabular}

$\mathrm{IC}_{50}=$ the half maximal inhibitory concentration

Values followed by the asterisk symbol $(*)$ are statistically significant $(\mathrm{p}<0.05)$ compared to the highest value of each activity based on Dunnett's multiple comparisons test. 
extracts decreased the highest value in $M$. coreia wood $\left(\mathrm{IC}_{50}=918.27 \pm 0.16 \mu \mathrm{g} \mathrm{ml}^{-1}\right)$ and the lowest in C. tomentosa wood $\left(\mathrm{IC}_{50}=8295.09 \pm 641.25 \mu \mathrm{g} \mathrm{ml} \mathrm{m}^{-1}\right)$. Reactive oxygen species, such as superoxides, give rise to the generation of dangerous hydroxyl radicals, which contribute to oxidative stress and damage lipids, proteins and DNA (50). The results of our study reveal that Rubiaceae plants have an effective capacity in scavenging for superoxide radical.

\section{Ferric reducing antioxidant power activity}

The ferric reducing capacity of plant extracts may serve as an indicator of its potential antioxidant activity, where the presence of an antioxidant reduces $\mathrm{Fe}^{3+}$-TPTZ to $\mathrm{Fe}^{2+}$ under acidic conditions. Thus, ferric reducing ability can be evaluated by the formation of a $\mathrm{Fe}^{2+}-\mathrm{TPTZ}$ complex. According to the FRAP activities in Table 2, the ferric reducing effects of plant extracts have the highest value in $M$. coreia wood $\left(236.65 \pm 1.66 \mathrm{mg} \mathrm{TE} \mathrm{g}^{-1}\right)$ and lowest value in $M$. coreia bark $\left(18.75 \pm 0.52 \mathrm{mg} \mathrm{TE}^{-1}\right)$. The reducing power of the test, the presence of reductants (antioxidants) in the solution causes the reduction of the $\mathrm{Fe}^{3+}$ - TPTZ complex to ferrous form (51). Our results show that the extracts act as an electron donor and thus, influence the reduction of the $\mathrm{Fe}^{+3}$ TPTZ complex to ferrous form.

\section{Ranking of antioxidant activity}

As shown in Table 3, the antioxidant activity of the extracts in our study are ranked as follows: $C$. tomentosa bark $>M$. coreia wood $>M$. diversifolia bark $>M$. rotundifolia bark $>C$. tomentosa wood and $H$. cordifolia bark $>M$. rotundifolia wood $>H$. cordifolia wood $>M$. diversifolia wood $>M$. coreia bark. The comparison of these results suggests that the level of anti-oxidant of species of Rubiaceae in diffirent bark and wood part are depend on the part and the spieces. Regarding the highest value of TPC, TFC and each antioxidant activity (Table 1 and 3), our results show that antioxidants in wood extracts are more effective than those in the bark extracts in TPC, TFC, NO radical scavenging, and FRAP activities. Other studies also suggest that wood extract has higher antioxidant activity than bark that is directly activity to polyphenols, which may be contributable to proteins, that could be oxidized using the Folin reagent and aluminum chloride (53-55). This may be further explained by the interference of other chemical components in the extract (56).

\section{Correlation with phytochemical constituents and $I C_{50}$ values of antioxidant}

The correlation between the TPC and TFC and antioxidant activity, including DPPH, NO and SO radical scavenging activity and FRAP activity of bark and wood were analysed (Tables 4 and 5). Specifically, a correlation coefficient of (r) > 0.6 shows extracts with strong antioxidant activity (57). Analysis of the strong correlation between the phenolic content and antioxidant activities showed that the TPC exhibits radical scavenging ability as follow; DPPH scavenging activity of $H$. cordifolia bark $(\mathrm{r}=0.9667)$ and wood $(\mathrm{r}=0.8048), M$. diversifolia wood ( $\mathrm{r}=0.8922), M$. rotundifolia wood ( $\mathrm{r}=0.9977)$ and $M$. coreia bark $(\mathrm{r}=0.6386)$; NO scavenging activity of $C$. tomentosa bark $(\mathrm{r}=0.8879)$ and wood $(\mathrm{r}$ $=0.7538), H$. cordifolia wood $(\mathrm{r}=0.6858), M$. rotundifolia wood $(\mathrm{r}=0.9479)$ and $M$. coreia wood $(\mathrm{r}$ $=0.6869)$; SO scavenging activity of $M$. diversifolia bark $(\mathrm{r}=0.8102)$ and $M$. coreia bark $(\mathrm{r}=0.8061)$; and FRAP of $H$. cordifolia wood $(\mathrm{r}=0.7559) M$. diversifolia bark $(\mathrm{r}=0.9449)$ and wood $(\mathrm{r}=0.8030)$ and $M$. rotundifolia bark $(\mathrm{r}=0.9449)$. The correlation analysis of flavonoid content and antioxidant activities show as follow; DPPH scavenging activity of C. tomentosa wood ( $\mathrm{r}=0.6171), H$. cordifolia bark $(\mathrm{r}=$ 0.7763), $M$. diversifolia wood $(\mathrm{r}=0.8372), M$. rotundifolia bark ( $\mathrm{r}=0.9983)$, and $M$. coreia wood $(\mathrm{r}=$ 0.8445); and SO scavenging activity of $C$. tomentosa bark $(\mathrm{r}=0.9895), M$. rotundifolia wood $(\mathrm{r}=0.9342)$, and $M$. coreia wood $(\mathrm{r}=0.9100)$ respectively. Interestingly, the correlation of flavonoid content and FRAP showed that all plant extracts exhibit the high correlation coefficient except $C$. tomentosa wood ( $\mathrm{r}=$ 0.4825 ), while no correlation was observed between flavonoids and nitric oxide radicals or between phenolic and flavonoid contents and antioxidant activities. Antioxidant activity can be determined by ranking TPC and TFC from greatest to least, which

Table 3. Ranking of anti-oxidant activity, total phenolic and total flavonoid content.

\begin{tabular}{|c|c|c|c|c|c|c|}
\hline Plant extracts & Part & $\begin{array}{c}\text { DPPH } \\
\text { ranking }\end{array}$ & $\begin{array}{l}\text { NO } \\
\text { ranking }\end{array}$ & $\begin{array}{c}\text { SO } \\
\text { ranking }\end{array}$ & $\begin{array}{c}\text { FRAP } \\
\text { ranking }\end{array}$ & Antioxidant rank \\
\hline Catunaregam tomentosa & bark & $5^{\mathrm{ns}}$ & 1 & $5^{* * * *}$ & $3^{* * * *}$ & 1 \\
\hline Catunaregam tomentosa & wood & $2^{\text {ns }}$ & $4^{* *}$ & $10^{* * * *}$ & $6^{* * * *}$ & 5 \\
\hline Haldina cordifolia & bark & $3^{\text {ns }}$ & $8^{* * * *}$ & $7^{* * * *}$ & $4^{* * * *}$ & 5 \\
\hline Haldina cordifolia & wood & $4^{\text {ns }}$ & $9^{* * * *}$ & $2^{\text {ns }}$ & $9^{* * * *}$ & 8 \\
\hline Mitragyna diversifolia & bark & $8^{* * * *}$ & $3^{* * *}$ & $4^{* * * *}$ & $5^{* * * *}$ & 3 \\
\hline Mitragyna diversifolia & wood & $7^{* *}$ & $7^{* * * *}$ & $6^{* * * *}$ & $8^{* * * * *}$ & 9 \\
\hline Mitragyna rotundifolia & bark & $9^{* * * *}$ & $2^{*}$ & $3^{* * * *}$ & $7^{* * * *}$ & 4 \\
\hline Mitragyna rotundifolia & wood & $6^{*}$ & $6^{* * * *}$ & $9^{* * * *}$ & $2^{* * * *}$ & 7 \\
\hline Morinda coreia & bark & 1 & $10^{* * * *}$ & $8^{* * * *}$ & $10^{* * * *}$ & 10 \\
\hline Morinda coreia & wood & $10^{* * * *}$ & $5^{* * * *}$ & 1 & 1 & 2 \\
\hline
\end{tabular}

Values followed by the asterisk symbol $(*)$ from $\mathrm{IC}_{50}$ are statistically significant $(\mathrm{p}<0.05)$ compared to the highest value of each activity based on Dunnett's multiple comparisons test.

related to the phenolic content, which agrees with the highest value of phenolic content in wood extracts $(44,52)$. However, a non-significant correlation was observed between the TPC and TFC and antioxidant varies depending on plant species, growth and developmental stages, stress conditions and other factors $(58,59)$. Similar to previous reports, our results reveal a positive relationship between TPC 
Table 4. Correlation between total phenolic content (TPC) and anti-oxidant activities of each plant extract; correlation coefficients were analysed at the $95 \%$ confidence interval.

\begin{tabular}{|c|c|c|c|c|c|}
\hline \multirow{2}{*}{ Plant extracts } & \multicolumn{5}{|c|}{ correlation coefficient $(r)$} \\
\hline & Part & DPPH & NO & SO & FRAP \\
\hline Catunaregam tomentosa & bark & -0.2603 & 0.8879 & -0.1446 & 0.0275 \\
\hline Catunaregam tomentosa & wood & -0.6171 & 0.7538 & 0.2438 & 0.4825 \\
\hline Haldina cordifolia & bark & 0.9667 & -0.5081 & -0.9541 & 0.2127 \\
\hline Haldina cordifolia & wood & 0.8048 & 0.6858 & -0.9958 & 0.7559 \\
\hline Mitragyna diversifolia & bark & -0.5000 & -0.8874 & 0.8102 & 0.9449 \\
\hline Mitragyna diversifolia & wood & 0.8922 & -0.7995 & -0.0262 & 0.8030 \\
\hline Mitragyna rotundifolia & bark & 0.4490 & -0.8470 & 0.1742 & 0.9449 \\
\hline Mitragyna rotundifolia & wood & 0.9977 & 0.9479 & -0.6307 & -0.9707 \\
\hline Morinda coreia & bark & 0.6386 & -0.9953 & 0.8061 & -0.8660 \\
\hline Morinda coreia & wood & -0.8198 & 0.6869 & 0.0316 & -0.6099 \\
\hline
\end{tabular}

Table 5. Correlation between total flavonoid content (TFC) and anti-oxidant activities of each plant extract. Correlation coefficient was analysed at $95 \%$ confidence interval.

\begin{tabular}{|c|c|c|c|c|c|}
\hline \multirow{2}{*}{ Plant extracts } & \multicolumn{5}{|c|}{ correlation coefficient $(r)$} \\
\hline & Part & DPPH & NO & SO & FRAP \\
\hline Catunaregam tomentosa & bark & -0.9655 & -0.4600 & 0.9895 & 0.9996 \\
\hline Catunaregam tomentosa & wood & 0.6171 & -0.7538 & -0.2438 & -0.4825 \\
\hline Haldina cordifolia & bark & 0.7763 & -0.9953 & -0.8042 & 0.9148 \\
\hline Haldina cordifolia & wood & 0.1612 & -0.0176 & -0.7763 & 0.9982 \\
\hline Mitragyna diversifolia & bark & -0.9286 & -0.9824 & 0.2740 & 0.9177 \\
\hline Mitragyna diversifolia & wood & 0.8372 & -0.9199 & -0.8788 & 0.9177 \\
\hline Mitragyna rotundifolia & bark & 0.9983 & -0.8839 & -0.7657 & 0.7559 \\
\hline Mitragyna rotundifolia & wood & -0.8302 & -0.9802 & 0.9342 & 0.9608 \\
\hline Morinda coreia & bark & -0.9857 & 0.5818 & -0.9155 & 0.8660 \\
\hline Morinda coreia & wood & 0.8445 & -0.9354 & 0.9100 & 0.9664 \\
\hline
\end{tabular}

and TFC and antioxidant ability from Trifolium pratense (60). However, no significant correlation was observed between highest TPC and TFC and antioxidant activity in samples, which may be because of interference from other antioxidant chemical components (49). Moreover, phenolic content was correlated with DPPH radical scavenging and ferric reducing antioxidant potential activities, suggesting a relation between TPC and TFC and antioxidant activity in Garcinia lasoar bark, as similarly quantified by researchers (61). Our results revealed that $M$. rotundifolia revealed that the correlation between the TFC and DPPH radical scavenging and FRAP activities were relatively higher $\left(\mathrm{DPPH} ; \mathrm{R}^{2}=0.7612\right.$, FRAP; $\left.\mathrm{R}^{2}=0.751\right)$. The data of antioxidant activity corresponding to DPPH and TPC had a very low correlation coefficient $\left(\mathrm{R}^{2}=0.00008\right)$, which has also been reported (37). Further, our analysis shows no significant correlation between TFC and NO radical scavenging activity, agreeing with a published report that TPC and TFC of Launaea procumbens extract have no correlation with NO radical scavenging activity (62). While several flavonoids may scavenge NO pro-oxidant properties by increasing superoxide, flavanones and flavonoid glycosides did not show significant inhibition of NO production up to $100 \mu \mathrm{M}$ (63). Besides NO, under oxidative stress conditions, flavonoids may also protect $\mathrm{NO}$ from $\mathrm{O}_{2}$-driven inactivation and inhibit NO-scavenging effects. Therefore, the effect of flavonoids on NO levels depends on the structure and the concentrations (64). Our results further suggest that the plant extracts contain phytochemical constituents that are capable of donating hydrogen to a free radical to scavenge the potential damage.

\section{Conclusion}

This work reveals the antioxidant ability of Rubiaceae species due to the methanolic extracts from TPC in $M$. diversifolia wood and TFC in $H$. cordifolia wood. Further, $C$. tomentosa bark presented the highest antioxidant activity. However, it is pertinent to note that the categorization established among the species depends on the method used. To the best of our knowledge, this is the first report on the phytochemical contents and antioxidant activity of $M$. diversifolia and $M$. coreia. The results of our study reveal that medicinal plants of the Rubiaceae family offer a potential source of natural antioxidants.

\section{Acknowledgements}

This research was supported by "the Strengthening and Developing New Researcher Plan, in conformance with the Research and Innovation of Graduate Study Strategy of the National Research Council of Thailand (NRCT) as of the fiscal year 2019" and "The Graduate Program Scholarship from the Graduate School of Kasetsart University.”

\section{Authors' contributions}

SD provided conceptualisation and resources, review and edited the manuscript. RS collect plant samples, investigated experiment, analysed data, and wrote and edited the manuscript. All authors have read and agreed to the published version of the manuscript. 


\section{Conflict of interests}

The authors declare no conflict of interest.

\section{References}

1. Schieber M, Chandel NS. ROS function in redox signaling and oxidative stress. Curr Biol. 2014;24(10):R453-62. https://doi.org/10.1016/j.cub.2014.03.034

2. Sharma P, Jha AB, Dubey RS, Pessarakli M. Reactive oxygen species, oxidative damage and antioxidative defense mechanism in plants under stressful conditions. J Bot. 2012;2012:1-26. https://doi.org/10.1155/2012/217037

3. Poljšak B, Fink R. The protective role of antioxidants in the defense against ROS/RNS-mediated environmental pollution. Oxid Med Cell Longev. 2014;2014:1-22. https://doi.org/10.1155/2014/671539

4. Paz-Elizur T, Sevilya Z, Leitner-Dagan Y, Elinger D, Roisman LC Livneh Z. DNA repair of oxidative DNA damage in human carcinogenesis: Potential application for cancer risk assessment and prevention. Cancer Lett. 2008;266:60-72. https://doi.org/10.1016/j.canlet.2008.02.032

5. Cichoż-Lach H, Michalak A. Oxidative stress as a crucial factor in liver diseases. World J Gastroenterol. 2014;20(25):8082-91. https://doi.org/10.3748/wjg.v20.i25.8082

6. Moreira P, Smith MA, Zhu X, Honda K, Lee HG, Aliev G, et al. Oxidative damage and Alzheimer's disease: are antioxidant therapies useful?. Drug News Perspect. 2005;18(1):13. https://doi.org /10.1358/dnp.2005.18.1.877164

7. Tan BL, Norhaizan ME, Liew WP, Sulaiman RH. Antioxidant and oxidative stress: A mutual interplay in age-related diseases. Front Pharmacol. 2018;9:1162. https://doi.org/10.3389/fphar.2018.01162

8. Colak E. New markers of oxidative damage to macromolecules. J Med Biochem. 2008;27:1-16. https://doi.org/10.2478/v10011007-0049-x

9. Mukherjee AB, Zhang Z, Chilton BS. Uteroglobin: a steroidinducible immunomodulatory protein that founded the secretoglobin superfamily. Endocr Rev. 2007;7:707-25. https://doi.org/10.1210/er.2007-0018

10. Hosseini A, Abdollahi M. Diabetic neuropathy and oxidative stress: therapeutic perspectives. Oxid Med Cell Longev. 2013;2013:168039. https://doi.org/10.1155/2013/168039

11. Beal MF. Mitochondria, oxidative damage, and inflammation in Parkinson's disease. N Y Acad Sci. 2003;991:120-31. https://doi.org/10.4061/2011/247467

12. Heinecke JW. Mechanisms of oxidative damage of low density lipoprotein in human atherosclerosis. Curr Opin Lipidol 1997;8:268-74. https://doi.org/10.1097/00041433-19971000000005

13. Sepulveda RT, Watson RR. Treatment of antioxidant deficiencies in AIDS patients. Nutr Res. 2002;22:27-37. https://doi.org/10.1016/S0271-5317(01)00355-4

14. Martins D, Nunez CV. Secondary metabolites from Rubiaceae species. Molecules. 2015;20(7):13422-95. https://doi.org/10.3390/molecules200713422

15. Heitzman ME, Neto CC, Winiarz E, Vaisberg AJ, Hammond GB. Ethnobotany, phytochemistry and pharmacology of Uncaria (Rubiaceae). Phytochemistry https://doi.org/10.1016/j.phytochem.2004.10.022

16. Lakić NS, Mimica-Dukić MN, Isak JM, Božin B. Antioxidant properties of Galium verum L. (Rubiaceae) extracts. Cent Eur J Biol. 2010;5: 331-37. https://doi.org/10.2478/s11535-010-0022-4

17. Torey A, Sasidharan S, Latha LY, Sudhakaran S, Ramanathan S Antioxidant activity and total phenolic content of methanol extracts of Ixora coccinea. Pharm Biol. 2010;48(10):1119-23. https://doi.org/10.3109/13880200903490505

18. Mavi A, Terzi Z, Özgen U, Yildirim A, Coşkun M. Antioxidant properties of some medicinal plants: Prangos ferulacea (Apiaceae), Sedum sempervivoides (Crassulaceae), Malva neglecta (Malvaceae), Cruciata taurica (Rubiaceae), Rosa pimpinellifolia (Rosaceae), Galium verum subsp. verum (Rubiaceae), Urtica dioica (Urticaceae). Biol Pharm Bull. 2004;27(5):702-05. https://doi.org/10.1248/bpb.27.702

19. Soobrattee MA, Bahorun T, Neergheen VS, Googoolye K, Aruoma OI. Assessment of the content of phenolics and antioxidant actions of the Rubiaceae, Ebenaceae, Celastraceae, Erythroxylaceae and Sterculiaceae families of Mauritian endemic plants. Toxicol In Vitro. 2008;22(1):45-56 https://doi.org/10.1016/j.tiv.2007.07.012

20. Parthasarathy S, Bin Azizi J, Ramanathan S, Ismail S, Sasidharan S, Said MIM et al. Evaluation of antioxidant and antibacterial activities of aqueous, methanolic and alkaloid extracts from Mitragyna speciosa (Rubiaceae Family) leaves. Molecules. https://doi.org/10.3390/molecules14103964

21. Tanase C, Coșarcă S, Muntean DLA. Critical review of phenolic compounds extracted from the bark of woody vascular plants and their potential biological activity. Molecules. 2019; 24:1182. https://doi.org/10.3390/molecules24061182

22. Beecher CWW, Farnsworth NR, Gyllenhaal C. Pharmacologically active secondary metabolites from wood. In: Rowe JW, (editor). Natural Products of Woody Plants. Berlin: Springer; 1989. p.1059-164.

23. Suksungworn R, Sanevas N, Wongkantrakorn N, Fangern N, Vajrodaya S, Duangsrisai S. Phytotoxic effect of Haldina cordifolia on germination, seedling growth and root cell viability of weeds and crop plants. NJAS - Wageningen Journal of Life $\quad$ Sciences. 2016;78:175-81. https://doi.org/10.1016/j.njas.2016.05.008

24. Aryal S, Baniya MK, Danekhu K, Kunwar P, Gurung R, Koirala $\mathrm{N}$. Total phenolic content, flavonoid content and antioxidant potential of wild vegetables from western Nepal Plants. 2019;8(4):96. https://doi.org/10.3390/plants8040096

25. Arvouet-Grand A, Vennat B, Pourrat A, Legret P Standardization of propolis extract and identification of principal constituents. J Pharm Belg. 1994;49:462-68.

26. Blois MS. Anioxidant determinations by the use of a stable free radical. Nature. 1958;181:1199-200.

27. Suksungworn $R$, Andrade $\mathrm{PB}$, Oliveira AP, Valentão $\mathrm{P}$, Duangsrisai S, Gomes NGM. Inhibition of proinflammatory enzymes and attenuation of IL-6 in LPS-challenged RAW 264.7 macrophages substantiates the ethnomedicinal use of the herbal drug Homalium bhamoense Cubitt \& W.W.Sm. Int J Mol Sci. 2020;21:2421. https://doi.org/10.3390/ijms21072421

28. Kuo CC, Shih MC, Kuo YH, Chiang W. Antagonism of freeradical-induced damage of adlay seed and its antiproliferative effect in human histolytic lymphoma U937 monocytic cells. J Agric Food Chem. 2001;49(3):1564-70. https://doi.org/10.1021/jf001215v

29. Hi F, Jia X, Zhao C, Chen Y. Antioxidant activities of various extracts from Artemisia selengensis Turcz. (LuHao). ex Bess. Molecules. https://doi.org/10.3390/molecules15074934

30. Gan RY, Xu XR, Song FL, Kuang L, Li HB. Antioxidant activity and total phenolic content of medicinal plants associated with prevention and treatment of cardiovascular and cerebrovascular diseases. J Med Plant Res. 2010;4:2438-44. https://doi.org/10.5897/JMPR10.581

31. Kumboonma P, Sombatsri S. Antioxidant activities and total phenolic contents from Thai wild fruits. KKU Sci J. 2019;47(1):34-42.

32. Hossain MAA, Hossain MS, Fatema K., Siddique BA, Sikder H, Sarker MS, et al. An evaluation on antioxidant activity, total phenolic and total flavaonoid contents of extracts from Adina cordifolia (Roxb.) Hook: f. ex. Brandis. American Journal of $\begin{array}{lll}\text { Plant } & \text { Sciences. } & \text { 2015;6:633-39. }\end{array}$ https://doi.org/10.4236/ajps.2015.65068

33. Begum S, Banerjee AB. Analysis of antioxidant activities, phenolic and other metabolites of some biomass waste (leaves) of India. Free Radicals and Antioxidants. 2018;8(2):102-10. https://doi.org/10.5530/fra.2018.2.16

34. Kumari S, Verma SM, Kumar H, Kyal CK. Evaluation of antibacterial, antioxidant, wound healing properties of different solvent fractions of Adina cordifolia leaves in 
experimental animals. Advances in Research. 2017;12(1):1-13. https://doi.org/10.9734/AIR/2017/36610

35. Baral P, Dubey A, Tewari S, Vasmatkar P, Verma AK. Total polyphenolic contents and antioxidant activity of leaf, bark and root of Adina cordifolia Benth. \& Hook. Journal of Pharmaceutical, Chemical and Biological Sciences. 2016;4(3):394-401.

36. Raypal P, Vermal AK, Tewari S, Dubey A. Analysis of medicinally important phytocompounds from Adina cordifolia leaves. Int J Curr Microbiol App Sci. 2018;7(11):3007-19. https://doi.org/10.20546/ijcmas.2018.711.345

37. Kang W, Li C, Liu Y. Antioxidant phenolic compounds and flavonoids of Mitragyna rotundifolia (Roxb.) Kuntze in vitro. Med Chem Res. 2010;19:1222-32. https://doi.org/10.1007/s00044009-9265-x.

38. Dimitrios B. Sources of natural phenolic antioxidants. Trends $\begin{array}{lll}\text { Food Sci } & \text { Technol. } & \text { 2006;17(9):505-12. }\end{array}$ https://doi.org/10.1016/j.tifs.2006.04.004

39. Chandini SK, Ganesan P, Bhaskar N. In vitro antioxidant activities of three selected brown seaweeds of India. Food Chem. https://doi.org/10.1016/j.foodchem.2007.08.081

40. Abdelwahab S, Abdul AB, Elhassan MM, Mohan S, Al-Zubairi $\mathrm{AS}$, Taha $\mathrm{M}$ et al. Antimicrobial and free radical scavenging activities of dichloromethane extract of Goniothalamus umbrosus. Int J Trop Med. 2009;4:32-36.

41. Rice-Evans CA, Miller NJ, Paganga G. Structure-antioxidant activity relationships of flavonoids and phenolic acids. Free Radic Biol Med. 1996;20(7):24. https://doi.org/10.1016/08915849(95)02227-9.

42. Kumar S, Pandey AK. Chemistry and biological activities of flavonoids: an overview. Scientific World Journal. 2013;2013:162750. https://doi.org/10.1155/2013/162750.

43. Chang ST, Wu JH, Wang SY, Kang PL, Yang NS, Shyur LF. Antioxidant activity of extracts from Acacia confusa bark and Heartwood. Journal of Agricultural and Food Chemistry. 2001;49(7):3420-24. https://doi.org/10.1021/jf0100907

44. Wang SY, Wu JH, Cheng SS, Lo CP, Chang HN, Shyur LF, et al. Antioxidant activity of extracts from Calocedrus formosana leaf, bark and heartwood. Journal of Wood Science. 2004; 50(5):422-26. https://doi.org/10.1007/s10086-003-0580-4

45. Escarpa A, Gonza'lez MC. Approach to the content of total extractable phenolic compounds from different food samples by comparison of chromatographic and spectrophotometric methods. Anal Chim Acta. 2001;427:119-27. https://doi.org/10.1016/S0003-2670(00)01188-0

46. González J, Cruz JM, Domínguez H, Parajó JC. Production of antioxidants from Eucalyptus globulus wood by solvent extraction of hemicellulose hydrolysates. Food Chem. 2004;84(2):243-51.

https://doi.org/10.1016/S0308-8146(03)00208-5

47. Pawar C, Surana S. Antioxidant properties of the methanol extract of the wood and pericarp of Caesalpinia decapetala. J Young Pharm. 2010;JYP2(1):45-49. https://doi.org/10.4103/09751483.62212

48. Saeed N, Khan MR, Shabbir M. Antioxidant activity, total phenolic and total flavonoid contents of whole plant extracts Torilis leptophylla L. BMC Complement Altern Med. 2012;12:211. https://doi.org/10.1186/1472-6882-12-221.

49. Govindan P, Muthukrishnan S. Evaluation of total phenolic content and free radical scavenging activity of Boerhavia erecta. Journal of Acute Medicine. 2013;3(3):103-39. https://doi.org/10.1016/j.jacme.2013.06.003.
50. Parejo I, Viladomat F, Bastida J, Rosas-Romero A, Flerlage N Burillo J, et al. Comparison between the radical scavenging activity and antioxidant activity of six distilled and nondistilled mediterranean herbs and aromatic plants. J Agric Food Chem. 2002;50(23):6882-90. https://doi.org/10.1021/jf020540a

51. Hong Y, Yidan S, Li Z, Yanan Z, Yuling Y, Lan D, et al. Antioxidant activities of malt extract from barley (Hordeum vulgare L.) toward various oxidative stress in vitro and in vivo. $\begin{array}{lll}\text { Food } & \text { Chem. 2010;118(1):84-89 }\end{array}$ https://doi.org/10.1016/j.foodchem.2009.04.094

52. Lamounier KC, Cunha LCS, de Morais SAL, de Aquino FJT, Chang $\mathrm{R}$, do Nascimento EA, et al. Chemical analysis and study of phenolics, antioxidant activity and antibacterial effect of the wood and bark of Maclura tinctoria (L.) D. Don ex Steud. Evid Based Complement Alternat Med. 2012;2012:451039. https://doi.org/10.1155/2012/451039

53. Kai Y. Chemistry of extractives. In: Hon DS, Shiraishi N (editors). Wood and cellulosic chemistry. New York: Marcel Dekker; 1991.

54. Singleton VL, Orthofer R, Lamuela-Raventos RM. Analysis of total phenols and other oxidation substrates and antioxidants by means of Folin-Ciocalteu reagent. Methods Enzymol. 1999;299:152-78. https://doi.org/10.1016/S0076-6879(99)99017-1

55. Moon JK, Shibamoto T. Antioxidant assays for plant and food components. J Agri Food Chem. 2009;57:1655-66. https://doi.org/10.1021/jf803537k

56. Jing L, Ma H, Fan P, Gao R, Jia Z. Antioxidant potential, total phenolic and total flavonoid contents of Rhododendron anthopogonoides and its protective effect on hypoxia-induced injury in PC12 cells. BMC Complement Altern Med. 2015;15:287. https://doi.org/10.1186/s12906-015-0820-3

57. Ngamdee P, Wichai U, Jiamyangyuen S. Correlation between phytochemical and mineral contents and antioxidant activity of black glutinous rice bran and its potential chemopreventive property. Food Technol Biotechnol. 2016;54(3):282-89. https://doi.org/10.17113/ftb.54.03.16.4346

58. Prior RL, Wu X, Schaich K. Standardized methods for the determination of antioxidant capacity and phenolics in foods and dietary supplements. J Agric Food Chem. 2005;53:4290-302. https://doi.org/10.1021/jf0502698

59. Quideau S, Deffieux D, Douat-Casassus C, Pouységu L. Plant polyphenols: chemical properties, biological activities and synthesis. Angew Chem Int Ed Engl. 2011;50(3):586-621. https://doi.org/10.1002/anie.201000044

60. Esmaeili AK, Taha RM, Mohajer S, Banisalam B. Antioxidant activity and total phenolic and flavonoid content of various solvent extracts from in vivo and in vitro grown Trifolium pratense L. (Red Clover). BioMed Research International. 2015:12. https://doi.org/10.1155/2015/643285

61. Kainama H, Fatmawati S, Santoso M, Papilaya PM, Ersam T. The relationship of free radical scavenging and total phenolic and flavonoid contents of Garcinia lasoar PAM. Pharm Chem J. 2020;53:1151-57. https://doi.org/10.1007/s11094-020-02139-5

62. Khan RA, Khan MR, Sahreen S, Ahmed M. Assessment of flavonoids contents and in vitro antioxidant activity of Launaea procumbens. Chem Cent J. 2012;6(1):43 https://doi.org/10.1186/1752-153X-6-43

63. Kim HK, Cheon BS, Kim YH, Kim SY, Kim HP. Effects of naturally occurring flavonoids on nitric oxide production in the macrophage cell line RAW 264.7 and their structureactivity relationships. Biochem Pharmacol. 1999;58(5):759-65. https://doi.org/10.1016/s0006-2952(99)00160-4

64. Duarte J, Francisco V, Perez-Vizcaino F. Modulation of nitric oxide by flavonoids. Food Funct. 2014;5(8):1653-68. https:// doi.org/10.1039/c4fo00144c 